\title{
FEDERAL GIFT TAX EXCLUSIONS: GIFTS TO CORPORATIONS
}

$W_{\text {Hether a Donation to a corporation is regarded as a gift to the }}$ corporate entity or to its individual stockholders ${ }^{1}$ is a determination that has at least two crucial federal gift tax consequences. First, because a donor is allowed an annual exclusion of but $\$ 3,000$ for each donee, ${ }^{2}$ the taxable amount of the gift may largely depend upon judicial definition of the recipient. Secondly, where the donor is also a stockholder in the corporation, it has been urged that a ratable deduction in the taxable amount of the gift is indicated if the stockholders are deemed to be the donees, because of the logical impossibility of the donor's affecting a gift to himself. Infrequent consideration of these problems, coupled with a recent marked change in judicial response to analogous questions, ${ }^{3}$ has rendered hazardous any conclusion as to the continued validity of early precedents in this area. In this connection, a recent decision of the Court of Appeals for the Ninth Circuit, however, is significant in that it may well indicate the course of subsequent judicial interpretation.

In Heringer v. Commissioner, 4 the taxpayers had gratuitously conveyed jointly-held property to a corporation in which they and their eleven children were the sole stockholders. Each taxpayer claimed both

\footnotetext{
${ }^{2} \mathrm{~A}$ gift by a donor-corporation is treated as a gift by the stockholders, U.S. Treas. Reg. 108, $\S 86.2$ (a) (r) (r 943 ). This is done because the Internal Revenue Code of 1954 provides only for the taxing of gifts by individuals. 68A STAT. 403 (1954), 26 U.S.C.A. § 2501 (a) (Supp. 1956). Therefore, in order to bring the corporate donor within the statutory language, the Treasury Department has ignored the corporate entity and has ruled that the stockholders are the donors of the gift. Support for this position is also found in the committee reports accompanying the 1932 Act which gave this illustration- " $[\mathrm{A}]$ transfer of property by a corporation without consideration, or one less than adequate and fully in money or money's worth, to B would constitute a gift to B from the stockholders of the corporation.” H.R. RE.P. No. 708, 72nd Cong., ist Sess. 27 (1932).

These considerations of statutory language are not applicable to a corporation receiving a gift because the statute makes no provision for the character of the donec. The House Report, supra, however, suggests that it was the intent of Congress to have the stockholders treated as the donees, for it sets out this illustration- "A transfer by A to a corporation owned by his children would constitute a gift to the children."

2 "In the case of gifts (other than gifts of future interests in property) made to any person by the donor during the calendar year 1955 and subsequent calendar years, the first $\$ 3,000$ of such gift to such person shall not ... be included in the total amount of gifts made during such year." INT. REv. CODE OF 1954, § 2503 (b).

${ }^{3}$ See text at note 14 infra and following.

${ }_{235}$ F.2d 149 (9th Cir. 1956), cert. denied, 352 U.S. 927 (1956).
} 
an exclusion for each of the other stockholders and a reduction in the taxable amount of the gift attributable to him proportionate to his interest in the corporation. The Tax Court, sustaining the Commissioner's contention, held, however, that the corporate entity was the recipient of the gift, and, accordingly, allowed but one exclusion for each donor and no reduction in the amount of the gift. ${ }^{5}$ On appeal, the court of appeals, although implicitly rejecting the premise that the corporate entity was the donee, ${ }^{6}$ agreed, nonetheless, that no additional exclusions could be allowed, ${ }^{7}$ pointing out that the interest conveyed to each individual stockholder was of such a future nature as to be noncognizable for gift tax purposes. ${ }^{8}$ The court, however, did order a reduction in the taxable amount of the gift, proportionate to the interest which the donors held in the corporation, on the ground that, as to that aliquot portion of the transfer, the concomitant increase in the net worth of the corporation supplied the donors with adequate consideration. ${ }^{9}$

In its holding that the taxable amount of the gift should be diminished proportionately to the interest of the donors in the corporation, the court reflects its perception of the realities of the transfer. In the first case considering this question, no reduction in the taxable amount of the gift was permitted, the Board of Tax Appeals scrupulously observing the separate identities of the corporation and its stockholders. ${ }^{10}$ But, in

Stephen F. Heringer, 21 T.C. 607 (1954).

- The court of appeals did not state expressly that the stockholders would be regarded as the donees, but, rather, said that this question need not be decided because the stockholders, even if treated as the donees, would receive only a future interest in property for which no exclusion is allowed. See section 2503 (b) of the Internal Revenue Code of 1954, note 2 supra.

The exclusion for the corporation which had been permitted by the Commissioner of Internal Revenue and, subsequently, sustained by the Tax Court was not disturbed on appeal since that particular question was not contested.

${ }^{8}$ Section 2503 (b) of the Internal Revenue Code of 1954, note 2 supra, expressly excepts gifts of future interests in property from the $\$ 3,000$ statutory exclusion.

The taxable amount of a gift is that portion for which no consideration has been received by the donor. "Where property is transferred for less than an adequate and full consideration in money or money's worth, then the amount by which the value of the property exceeded the value of the consideration shall be deemed a gift. . . " INT. REv. CoDE OF 1954, $\$ 2512$ (b). This provision of the 1954 Code has been carried over intact from section 1002 of the 1939 Code. See also, Commissioner v. Wemyss, 324 U.S. $303,306(1945)$.

10 Frank B. Thompson, 42 B.T.A. 121 (1940), modified, 30 Am. Fed. Tax. R. 1534 (6th Cir. 1942). The Board in the Thompson case relied, to a great extent, upon a number of income tax cases in which the corporation had been treated as the donee for the purpose of determining the basis of long term capital gains. The question of whether the corporation or its stockholders were the donees, however, was never in issue. The Board cited Commissioner v. Rosenbloom Finance Corp., 66 F.2d 556 (3rd Cir. 1933); Bothin Real Estate Co. v. Commissioner, go F.2d 91 (gth Cir. 1937); and 
a subsequent case, where the donor was the sole stockholder of the donee corporation, the Board felt constrained to conclude that the enhanced value of the donor's interest in the corporation constituted full consideration for the transfer and thus held that there was no taxable gift. $^{11}$ In distinguishing the earlier case, it was explained that unless the donor were the sole stockholder, the difficulty in evaluating the "partial consideration" would compel taxation of the entire transfer. In the Heringer case, however, despite the multiplicity of stockholders, the court experienced no difficulty in reducing the taxable amount of the donors' gift in proportion to their interest in the corporation, ${ }^{12}$ reasoning that only as to the balance, for which adequate consideration was not supplied, could a gift tax properly be assessed. ${ }^{13}$ And even if the stockholders of the corporation were unequivocally regarded as the donees, it would still be clear that the total amount of the transfer would not be taxable-not on the theory that consideration had been supplied for a portion of the gift, but rather because of the logical impossibility of the donors' making a gift to themselves.

The principal significance of the decision, however, lies with its intimation that gifts to corporations are henceforth to be treated for tax -purposes like gifts in trust-a rationale suggesting possibly parallel development of the law in these two areas. Initially, gifts in trust were held to have been made to the trustees rather than to the beneficiaries. ${ }^{14}$

In Helvering v. Hutchings, ${ }^{15}$ however, the Supreme Court held that it was the beneficiaries who were, in fact, the donees, recognizing that this construction accorded more closely with the probable intent of the

King v. United States, 79 F.2d 453 (4th Cir. 1935). In the Bothin and Rosenbloom cases, a sole stockholder transferred all his stock to his wholly-owned corporation and the transfer was held to be a gift. In the King case, on the other hand, a similar transfer was held to be a transfer for stock, not a gift, and a tax was levied on the profit resulting from the increase in the value of the stock.

The Thompson case has been subjected to severe criticism. See Lowndes AND Kramer, Federal Estate and Gift Taxes 672 (1956); 2 Paul, Federai, Estate and Gift Taxation 1087 (1942); Note, 50 Yale L. J. 335 (1940). However, there is little authority for a contrary holding. Einily C. Collins, I T.C. 605, 610 (1943) (dissenting opinion). In Diebold v. Commissioner, 194 F.2d 266 (3rd Cir. 1952), a bequest to a family corporation was held to be a bequest to the stockholders.

11 Robert H. Scanlon, 42 B.T.A. 997 (1940).

12 The amount of the reduction is computed by dividing the value of the property transferred by the percentage representing the donor's proportionate share of ownership in the corporation.

${ }^{13}$ See note 9 supra.

14 Commissioner v. Wells, 88 F.2d 339 (7th Cir. 1937); Commissioner v. Krebs, 90 F.2d 880 (3rd Cir. 1937).

16 i 3 U.S. 393 (19+1). See also, United States v. Pelzer, 312 U.S. 39.9 (19+1); Ryerson v. United States, 312 U.S. 405 (1941). 
settlor. ${ }^{16}$ The Court observed, moreover, that this change of tack not only removed an unreasonable discrimination against gifts made in trust and in favor of those made directly to the beneficiaries, but also obviated the possibility of tax avoidance through the ruse of setting up a number of trusts for a single beneficiary. ${ }^{17}$

Not surprisingly, in the first case in which the characterization of a gift to a corporation was put in issue, the Board of Tax Appeals also refused, as had the courts in the earlier trust cases, to look beyond the formalities of the transfer and held the corporate entity, rather than its stockholders, to be the donee. ${ }^{13}$ The Heringer case, however, intimates that the law governing gifts to corporations is evolving along the same lines as that governing gifts made in trust, and that the stockholders, as the beneficiaries, may eventually come to be regarded as the donees. Nor does there appear to be any sound basis for distinguishing between the two situations. Indeed, viewed realistically, the same considerations that induced the Supreme Court to hold a gift in trust to be a gift to the beneficiary would seem decisively to compel the analogous holding that a gift to a small family corporation is a gift to its stockholders. ${ }^{10}$

\footnotetext{
${ }^{10}$ Clearly, the settlor's intent is to give the property transferred to the trustee to the beneficiaries as donees, and the trust device is used only to insure a disposition fully in accord with the donor's wishes. As stated by the Supreme Court, "it would seem to follow that the beneficiary of the trust to whose benefit the surrender inures, whether made at the time the trust is created or later, is the 'person' or 'individual' to whom the gift is made." Helvering v. Hutchings, note 15 supra at 396 . See also, Welch $v$. Davidson, 102 F.2d 100, 102 (1st Cir. 1939), affirming 22 F. Supp. 726 (D. Mass. 1938 ), in which the court said that "a beneficiary under an irrevocable trust, who takes a present interest ... is the donee on whom the donor intended to bestow his bounty and ... the trustee, to whom he conveys the legal title devoid of any beneficial interest, is not."

"If the holdings in the Wells and Krebs cases, supra note 14, were followed, a donor could clain an exclusion for each of several trusts even if all of the trusts were created for the same beneficiary..

" Frank B. Thoinpson, 42 B.T.A. 221 (1940).

${ }^{10}$ A number of dummy corporations could be set up with the same stockholders which would allow, if carried far enough, inore exclusions than there are stockholders. "If ... a gift to a trust may be treated for tax purposes as several gifts to the intended beneficiaries, a bequest of stock of a family corporation, in terms to the corporation itself, may likewise be given effect as a bequest enlarging the proportional holding of the surviving stockholders." Diebold v. Commissioner, 194 F.2d 266, 269 (3rd Cir. 1952). See also, Note, 50 Yale L. J. 335 (1940) and Emily C. Collins, I T.C. 605, 610 (1943) (dissenting opinion).

Since the trust, however, is not a legal entity capable of owning property, it is easier, in the case of a gift to a trust as opposed to a gift to a corporation, to by-pass the trust as donee and find that the beneficiaries are the donees. "The trust is viewed in income tax law as a conduit: it will pay no income tax if it distributes its earnings to the beneficiaries. On the other hand, the corporation is regarded as a taxable entity, and of
} 
The court's suggestion that the interest of a shareholder in a gift to a corporation is a future one is novel $;^{20}$ yet, it seems fully compatible with the accepted definition of a future interest under the gift tax. ${ }^{21}$ For, although the value of the stockholder's shares in the corporation was increased, the transfer conferred no immediate individual right to

course cannot escape taxation by distributing its income to its shareholders." In the case of a gift in trust, the donor's intent is to donate property to the bencficiaries. (Sec note 16 supra.) However, "the transferor (to a corporation) may wish to further his own interests by the transfer rather than to benefit the other sharcholders." Note, Tax Consequences of (jifts of Property to Closely Held Corporations, 66 Harv. L. REv. $334,339-40(1952)$.

"That the gift to the beneficiary of a trust is one of a future interest is fairly well-settled, however. Initially, the courts of appeals were split over the question. Compare Commissioner v. Wells, 88 F.2d 339 (7th Cir. 1937) suith Commissioner v. Krebs, 90 F.2d \$80 (3rd Cir. 1937).

In $H^{\prime}$ elch 0. Paine, 120 F.2d $1+1$ (1st Cir. 1941), 55 HARv. L. REv. 302, $A$ conveyed property to himself as trustee in trust for $C$. The court, applying the Restatement of Property definition of "future interest," held that the interest transferred was future in nature within the meaning of section $504(\mathrm{~b})$ of the 1939 Code. Sec also, Alma S. Hay, 47 B.T.A. 247 (19+2) and Rosa A. Howze, 2 T.C. 1254 (1943). In the latter case, a parent made a gift to his children, reserving a life estate to hiunself. It was held that this was a gift of a future interest, even though it was fully marketable as a vested remainder, and therefore no exclusion was permitted.

The Supreme Court, in $19+5$, attempted to answer the question in Fosdren $v$. Commissioner, $32 .+$ ['.S. 18,20 (1945), 44 Mich. L. REv. 321 . In that case, $A$ conveyed property to $T$ in trust for $C$ with a discretionary power in $T$ to use the income for $C$ 's support. The Court held that the gift to $C$ was a future interest, and, therefore, disallowed an exclusion for gift tax purposes. See also, Commissioner v, Disston, 325 U.S. $4+2,4+9(1945)$.

The decision of the Serenth Circuit in Kieckhefer 8 . Commissioner, 189 F.2d 118 (7th Cir. 1953), has presented new difficulties. In that case, $A$ conveyed to his son $T$ in trust for grandson $C$ and provided that $T$ could use the inconie from the trust property for $C$ s education and support. It was also provided that the trust would terminate upon demand by $C$ or his guardian. The court held that on these facts $C$ took a present interest in the property. The Rieckhefer decision resulted in a veritable storm of coinment. See Notes, 65 Harv. L. Rev. 703 (1952); 36 Minn. L. Rev. 295 (1952); 4 Stan. L. Rev. 428 (1952); 30 TeXas L. Rev. 258 (1953); 100 U. PA. L. Rev. 905 (1952); 37 VA. L. REv. I016 (1951). See also, Cavitch, Obtaining the Gift Tax Exclusion on Gifts in Trust: Drafting and Legislative Suggestions, 5i Mich. L. Rev. 621 (1953); Comment, 53 Colum. L. Rev. 530 (1953).

${ }_{21}$ " [I]t is necessary to put aside conceptions of 'estates in futuro' as understood by Blackstone and the classic commentators on the common law. For future estates, as the term is used in the statute, are not to be understood as interests similarly designated in the law of conveyancing. They are, rather, interests in land or other things, in which the privilege of possession or of enjoyment is future and not present; and the ouse essential is the possibility of future enjoyment." (Emphasis added.) Commissioner v. Wells, 132 F.2d 405, 407 (6th Cir. 1942). See also, United States v. Pelzer, 312 U.S. $399(19+1)$.

"The definition of future interests, of course, is not necessarily the same as the property law definition; in fact, it is somewhat more inclusive. The Bureau (of Internal Revenue) has included in it all interests, vested or contingent, which ars limited to commence in use, possession or enjoyment at some future date or time." Comment, 53 Colum. L. Rev. 530, 531 (1953). 
possess or enjoy the gift; only through a concerted action by a majority of the shareholders, could any one of them gain a present interest in the corporate assets. ${ }^{22}$ Definitionally, at least, it seems improbable that any court could reach a different conclusion, although, arguably, since the stockholder has the present right to sell his share in the corporation for an increased price that reflects the value of the gratuitous transfer, he thereby has present possession and enjoyment of the gift. This latter criterion, however, has been rejected; the test is rather-does the donee actually have the present power to possess and enjoy the particular gift transferred? ${ }^{23}$

The holding of the Ninth Circuit in the Heringer case that a gift to a corporation should be reduced in proportion to the interest held by the donor stockholder clearly comports with the Supreme Court's mandate that substance, not form, is to govern in the tax field. ${ }^{24}$ Although the court does not explicitly determine whether a gift to a corporation is a gift to the corporate entity or one to the shareholders, it rather clearly implies that the latter are now to be considered the donees. ${ }^{2-5}$ And the suggestion that the interest which they take is a future interest, for which no exclusion is allowed, may well reverse the positions of the taxpayer and the Commissioner and, thus, prompt litigation which will result in a final resolution of this question. ${ }^{26}$

\footnotetext{
22 Only by such concerted action could liquidation and distribution of the corporate assets be effected, and, to that extent, the gift to the shareholders, if they are deemed to be the donees, cannot be termed present in nature. See, Skouras v. Commissioner, 188 F. 2 d 831 (zd Cir. 1951), citing United States v. Pelzer, $3: 2$ U.S. 399 (1941) and Ryerson v. United States, 312 U.S. 405 (1941).

${ }^{23}$ That this is the test is indicated by the holdings that a gift of a reversion or of a remainder is a gift of a future interest although such property interests are readily marketable. See, Welch v. Paine, 120 F.2d 14 I (1st Cir. I 94I); Rosa A. Howze, ? T.C. 1254 (1943); Alma S. Hay, +7 B.T.A. 247 (1942).

as Helvering v. Hutchings, 3 i 2 U.S. 393,397 (1941).

${ }^{25}$ See note 6 supra.

${ }^{20}$ If a gift is one of a future interest to the stockholders, the Comnissioner will allow no exclusions, and the taxpayer, in order to be entitled to at least one exclusion, will claim that the gift is one to the corporation. Thus, the issue of who is the clonee will be raised directly.
} 


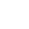

